\title{
Limitations in Activities of Daily Living in Individuals With Chronic Kidney Disease: Biopsychosocial Factors of the Brazilian Population
}

Hellen Carvalho Lima

Federal University of Vale São Francisco

Carla Daniele Ferreira Dantas

Federal University of Rio Grande do Norte

Adson Aragão Araújo Santos

Federal University of Vale São Francisco

Adirlene Pontes Oliveira Tenório

Federal University of Vale São Francisco

Marcello Barbosa Otoni Gonçalves Guedes

Federal University of Rio Grande do Norte

Thais Sousa Rodrigues Guedes

Federal University of Rio Grande do Norte

Matheus Rodrigues Lopes

Federal University of Vale São Francisco

Clecio Gabriel Souza

Federal University of Rio Grande do Norte

Rodrigo Pegado

Federal University of Rio Grande do Norte

Johnnatas Mikael Lopes ( $\boldsymbol{\sim}$ johnnataslopes@univasf.edu.br)

Federal University of Vale São Francisco

\section{Research Article}

Keywords: Chronic Kidney Disease, Quality of Life, Public Policy, Physical Limitation

Posted Date: December 20th, 2021

DOI: https://doi.org/10.21203/rs.3.rs-1156980/v1

License: (c) (1) This work is licensed under a Creative Commons Attribution 4.0 International License.

Read Full License 


\section{Abstract}

This study assesses the relationship between biopsychosocial factors and limitations in activities of daily living (ADL) in individuals with chronic kidney disease (CKD). Individual data from the National Health Survey were analyzed, with a sample size of 839 participants. The outcome was dichotomous, presenting limitations in $A D L$, and the factors considered were clinical and health characteristics, selfperceived behavior, contextual social support, and housing. Cox regression was applied to control the interaction between factors, using the prevalence ratio as a measure of effect and a significance level of 5\%. A total of 839 individuals with CKD were reported, of which 373 (40.7\%: 35.4 - 46.1\%) reported having limitations in ADL. The presence of limitations in ADL was related to residing in a rural area, as well as to the absence of private health insurance, worse self-perceived health, presence of depressive symptoms, and disabilities, in addition to the use of medications and hemodialysis. Limitations in ADL in individuals with CKD are associated with biopsychosocial factors in the Brazilian population, requiring public policies that enable better therapeutic management and support for behavioral health and contextual needs.

\section{Introduction}

Chronic kidney disease (CKD) is a functional or structural renal abnormality present for a period greater than three months, with repercussions on the health of the individual due to the accumulation of metabolic degradation products in the blood. It can be classified according to its cause, glomerular filtration rate, and level of albuminuria (KETTELER et al., 2017). This health condition has a great physiological impact on the human body and, therefore, the activities of daily living (ADL), which can be subdivided into basic and instrumental ADL (CHIN et al., 2014). Basic ADLs are human tasks related to physiological needs such as eating and sphinctering, while instrumental ADLs are tasks that have an interface with the context such as shopping and household care (WATANABE et al. 2018).

There is a wide range of diverse etiologies for CKD, such as diabetic nephropathy, systemic arterial hypertension and glomerulonephritis, pyelonephritis, urinary tract obstruction, and abusive use of drugs or other nephrotoxic agents. Diverse complications commonly occur in CKD and include anemia, metabolic acidosis, mineral and bone disorders, and malnutrition, in addition to death, especially due to cardiovascular complications and functional renal failure (THOME et al., 2017; WEBSTER et al., 2017).

CKD has an estimated global prevalence of $8-16 \%$ and is the third leading cause of life expectancy decreases. In Brazil, the dialysis census of 2017 revealed 40 thousand new patients, an increase of $2 \%$ in the prevalence rate of hemodialysis patients compared to the previous year. (HILL et al., 2016; THOME et al., 2017). CKD could be asymptomatic in its early stages but with the progression of the disease, which may be associated with a varied spectrum of functional limitations and restrictions due to their clinical condition (CHIN et al., 2014).

The progression of this disease varies according to ethnic, economic and social factors, with the population of the most vulnerable socioeconomic classes being $60 \%$ more likely to develop CKD 
(WEBSTER et al., 2017). The socioeconomic profile of individuals with CKD in Brazil expresses a predominance of male persons, with an age range from 40 to 59 years, black and brown color/ethnicity, low education level, and income between 1 and 2 minimum wages (LANZA et al., 2008; SAMPAIO et al., 2013; OLIVEIRA JUNIOR et al., 2014; RIBEIRO et al., 2014). It is possible that these conditions of illness and access to care are also conditions of human functionality, worsening the status of health and quality of life (CRUZ et al. 2011).

It is worth noting that many patients still undiagnosed or in conservative nondialytic treatment present reductions in renal function and $A D L$. In addition to the dependence on drugs or renal replacement therapy, individuals with CKD still meet limitations in their functional life that require changes in lifestyle, such as the consumption of healthy food, practice of physical exercises, abstaining from alcoholism and smoking (OLIVEIRA et al., 2016; MORAES et al., 2018).

In this context, patients with CKD have limitations in ADL, leisure, work, and social activities. The prevalence of anxiety and depression symptoms sums to these limiting factors originating both from these limitations and from the dependence on a treatment that shall extend for life (OTTAVIANI et al., 2016; RAMÍREZ-PERDOMO; SOLANO-RUÍZ, 2018).

In this manner, this study aims to estimate the individual and contextual factors that are associated with CKD patients with limitations in ADL in the Brazilian population.

\section{Method}

\section{Study design}

This is a cross-sectional study based on data from the National Health Survey (NHS) performed in Brazil in 2013, developed by the Brazilian Institute of Geography and Statistics in partnership with the Oswaldo Cruz Foundation. The survey was approved by the National Research Ethics Commission under protocol number 10853812.7.0000.0008. This study was based on secondary data (with open access) from the $\mathrm{NHS}$ collected from the official website of Ministry of Health. According to National Health Council Resolution 466/2012 and 510/2016, this study does not require ethical committee approval or informed consent statement.

\section{Setting}

Sample sizing was calculated based on data of the whole population extracted from the 2010 census applied by the Brazilian Institute of Geography and Statistics, estimating a sample size of 81,357 individuals with age greater than 18 years. From this primary sample, there were 60202 respondents, of which 839 had a diagnosis of CKD. Sampling was made based on conglomerates and first involved the census sector, followed by the households in the sector, and then by the resident. In the last two stages, simple random sampling was used (SOUZA-JUNIOR et al., 2015). 
The outcome of the study was the presence or absence of limitations in instrumental ADL caused by CKD condition, inquired by the following question: "In general, to what degree does renal insufficiency limit your daily activities (such as working and performing household services, etc.)?" and answered as "does not limit" (1), "a little" (2), "moderately" (3), "intensely" or "very intensely" (4), which were then dichotomized as "does not limit" and "limited". The choice of this classification is due to methodological issues for the construction of an explanatory model, which is influenced by the outcome response variability and the number of independent variables.

\section{Participants}

The NHS population included permanent private residents, grouped into census sections in capitals, metropolitan areas, and inland cities, excluded indigenous villages, military bases and barracks, camping areas, motels, boats, penitentiaries, penal colonies, prisons, almshouses, orphanages, convents, and hospitals (SOUZA-JUNIOR et al., 2015).

\section{Variables}

The independent variables considered were sociodemographic: sex (male/female), age (years), lives with a partner (yes/no), color/race (white/nonwhite), social class according to the Brazil criterion, occupation (paid/unpaid), education level (graduation/postgraduation, high school, primary school, preschool, and illiterate), area of residence (urban/rural), and health insurance (yes/no).

\section{Data sources and measurement}

The participants first answered a research instrument organized by thematic modules from A to W, and the modules that involved the individual characteristics of the residents were analyzed, such as demographic and social characteristics, lifestyle, health perception, chronic diseases, and household characteristics (SOUZA-JUNIOR et al., 2015).

The "health" dimension variables were drug use for the CKD condition (yes/no); undergoes hemodialysis (yes/no); undergoes peritoneal dialysis (yes/no); underwent kidney transplantation (yes/no); age at CKD diagnosis (years); carrier of other noncommunicable diseases (NCDs) (yes/no); carrier of physical or mental disability (yes/no); carrier of hypertension (yes/no); last doctor visit (last twelve months, from 1 to 2 years, from 2 to 3 years, and 3 years or more); frequency of family health strategy visits (monthly, less than monthly, or never).

The self-perception variables were health (good/average/poor), behavioral oscillation (yes/no), and depressive symptoms (yes/no). The "lifestyle" variables consisted of smoking habits (yes, daily; yes, less than daily; and no current smoke); alcohol use (yes/no); practice of physical exercises for at least 150 minutes per week (yes/no); family social support ( $\leq 1$ person, 2-3 people, and 4 or more people); and friend social support ( $\leq 1$ person, 2-3 people, and 4 or more people).

\section{Statistical methods}


In the complex sampling performed, data analysis was based on the weighted estimation of the sampling units from the last stage. Data were described as prevalence estimates, with a $95 \%$ confidence interval $(95 \% \mathrm{Cl})$. The relationships between the outcomes and the independent variables occurred through the Cox regression model, with adjustment for a complex design, and by Wald chi-square significance test. Furthermore, the prevalence ratio (PR) was estimated as a measure of effect, and $a \leq 0.05$.

\section{Results}

The NHS identified 839 participants who reported a CKD diagnosis, which represents approximately $1.5 \%$ of the total and a variation in the Brazilian population within $1.3 \%$ to $1.7 \%$. Of these participants, 373 (40.7\%: 35.4\% - 46.1\%) reported limitations in ADL, 500 (57.2\%: 52.6\% - 61.8\%) were female, and 381 (53.1\%: 49.1 -57) were nonwhite. Most of these individuals reported living in the urban perimeter (86.9\%; IC 95\%: 85.8\% - 87.9\%), and 57.9\% (IC 95\%: 53.6\% - 62.0\%) did not exercised any paid work.

The analysis between the outcome and the independent variables revealed that being white $(P R=0.71$; $0.55-0.93)$ and having attended school $(P R=0.49 ; 0.29-0.85)$ were factors less associated with limitations in ADL in people with CKD, as well as living in urban areas $(P R=0.60 ; 0.47-0.75)$ and exerting paid work ( $P R=0.67 ; 0.49-0.89)$ when compared to their peers (Table 1 ).

Table 1: Descriptive and unadjusted analysis of sociodemographic and contextual variables. 

$\mathrm{N}(\%)$
$95 \%$ IC
$\beta$
t
p
$\mathrm{PR}_{\mathrm{u}} \quad 95 \% \mathrm{IC}$

Sex

\begin{tabular}{llllllll}
\hline Male & $\begin{array}{l}339 \\
(42.8 \%)\end{array}$ & $38.2-47.4$ & -0.15 & -1.04 & 0.29 & 0.85 & $\begin{array}{c}0.63- \\
1.14\end{array}$ \\
\hline Female & $\begin{array}{l}500 \\
(57.2 \%)\end{array}$ & $52.6-61.8$ & 0 & & & 1 & \\
& $53.74^{\star}$ & $\begin{array}{l}52.21- \\
55.27\end{array}$ & 0.001 & 0.12 & 0.89 & 1.001 & $0.99-$ \\
\hline Age (years) & & & & & & & \\
\hline Color or race & & & & & & & \\
\hline White & $\begin{array}{l}381 \\
(53.1 \%)\end{array}$ & $49.1-57.0$ & -0.33 & -2.47 & 0.01 & 0.71 & $0.55-$ \\
\hline Nonwhite & $\begin{array}{l}458 \\
(46.9 \%)\end{array}$ & $43.0-50.9$ & 0 & & & 1 & \\
\hline
\end{tabular}

Lives with a partner

\begin{tabular}{llllllll} 
Yes & $\begin{array}{l}470 \\
(70.3 \%)\end{array}$ & $66.4-73.8$ & -0.25 & -2.28 & 0.02 & 0.77 & $\begin{array}{l}0.62- \\
0.96\end{array}$ \\
\hline No & & & & & & 1 \\
& $\begin{array}{l}369 \\
(29.7 \%)\end{array}$ & $26.2-33.6$ & 0 & & & 1 & \\
\hline
\end{tabular}

Education level

\begin{tabular}{llllllll}
\hline $\begin{array}{l}\text { Graduation/Post- } \\
\text { Grad }\end{array}$ & $\begin{array}{l}114 \\
(11.4 \%)\end{array}$ & $9.2-14.0$ & -0.37 & -1.21 & 0.22 & 0.68 & $\begin{array}{l}0.37- \\
1.25\end{array}$ \\
\hline High school & & & & & & & $0.21-$ \\
& $(24.1 \%)$ & $20.6-27.9$ & -0.91 & -2.87 & 0.004 & 0.39 & 0.74 \\
\hline
\end{tabular}

\begin{tabular}{llllllll}
\hline Primary school & 244 & $25.9-33.1$ & -0.76 & -2.51 & 0.01 & 0.46 & $0.25-$ \\
& $(29.4 \%)$ & & & & & & 0.84 \\
\hline
\end{tabular}

$\begin{array}{llllllll}\text { Preschool } & 204 & 22.6-29.6 & -0.61 & -1.98 & 0.04 & 0.53 & \begin{array}{l}0.29- \\ 0.99\end{array}\end{array}$

Illiterate

$79(9.25 \%)$

$6.8-12.4$

0

1

Health insurance

\begin{tabular}{llllllll} 
Yes & 217 & $30.7-38.8$ & -0.78 & -4.88 & $<0.001$ & 0.46 & $\begin{array}{l}0.33- \\
0.63\end{array}$ \\
\hline No & $(34.6 \%)$ & & & & & & 1 \\
& $\begin{array}{llll}622 \\
(65.4 \%)\end{array}$ & $61.2-69.3$ & 0 & & & 1 & \\
\hline
\end{tabular}

Area of residence

Urban

$\begin{array}{lllllll}676 & 85.8-87.9 & -0.51 & 4.39 & <0.001 & 0.60 & 0.47- \\ (86.9 \%) & & & & & & 0.75\end{array}$


Rural

Paid work

\begin{tabular}{llllllll}
\hline Yes & 355 & $38.0-46.4$ & -0.40 & 2.68 & 0.008 & 0.67 & $\begin{array}{l}0.49- \\
0.89\end{array}$ \\
\hline No & $(42.1 \%)$ & & & & & & 1 \\
& $\begin{array}{l}484 \\
(57.9 \%)\end{array}$ & $53.6-62.0$ & & & & & \\
\hline Social class & $19.45^{\star}$ & $\begin{array}{l}18.76- \\
20.15\end{array}$ & -0.34 & -3.28 & 0.001 & 0.70 & $0.57-$ \\
& & & & & & & 0.87
\end{tabular}

${ }^{*}$ Continuous variable presented as a mean; $\mathrm{N}$ - number of participants; \% - ratio; IC - Confidence interval; $\beta$ - Unadjusted regression coefficient; $t-t$ test for the comparison between levels; $g l$ - Degrees of freedom; $\mathrm{p}$ - Statistical significance; $\mathrm{PR}_{\mathrm{u}}$ - Unadjusted prevalence ratio.

Most individuals in the sample used medicines for CKD-related comorbidities (57.4\%: $51.6 \%$ - 62.09\%) and did not undergo hemodialysis (93.0\%: $89.7 \%$ - 95.3\%) or peritoneal dialysis (98.6\%: $97.2 \%$ - 99.3\%). It was possible to infer that those undergoing drug treatment and hemodialysis were more associated with limitations in ADL. Peritoneal dialysis and transplantation did not seem to reduce individual and social functionality (Table 2).

Table 2: Description of drug use, hemodialysis, peritoneal dialysis and kidney transplant in the Brazilian population with chronic kidney disease (CKD). 


\begin{tabular}{lllllllll} 
& $\mathrm{N}(\%)$ & $\mathrm{IC} 95 \%$ & $\beta$ & $\mathrm{t}$ & $\mathrm{p}$ & $\mathrm{PR}_{\mathrm{u}}$ & $\mathrm{IC95 \%}$ \\
\hline Age at CKD diagnosis & $40.26^{*}$ & $38.26-42.26$ & 0.01 & 0.82 & 0.41 & 1.00 & $0.99-1.01$ \\
\hline Drug use & & & & & & & \\
\hline Yes & $475(57.4)$ & $51.6-62.09$ & 0.58 & 4.67 & $<0.001$ & 1.79 & $1.40-2.29$ \\
\hline No & $364(42.6)$ & $37.1-48.4$ & 0 & & & 1 & \\
\hline Hemodialysis & & & & & & & \\
\hline Yes & $56(7.0)$ & $4.7-10.3$ & 0.88 & 4.72 & 0.001 & 2.41 & $1.67-3.48$ \\
\hline No & $783(93.0)$ & $89.7-95.3$ & 0 & & & 1 & \\
\hline Peritoneal dialysis & & & & & & & \\
\hline Yes & $12(1.4)$ & $0.7-2.8$ & 0.39 & 1.11 & 0.27 & 1.48 & $0.74-2.98$ \\
\hline No & $827(98.6)$ & $97.2-99.3$ & 0 & & & 1 & \\
\hline Kidney transplant & & & & & & & \\
\hline Yes & $17(1.9)$ & $1.0-3.3$ & 0.13 & 0.38 & 0.70 & 1.14 & $0.57-2.29$ \\
\hline No & $822(98.1)$ & $96.7-99.0$ & 0 & & & 1 & \\
\hline
\end{tabular}

*Continuous variable presented as a mean; $\mathrm{N}$ - number of participants; \% - ratio; IC - Confidence interval; $\beta$ - Unadjusted regression coefficient; $t-t$ test for the comparison between levels; $g l$ - Degrees of freedom; $\mathrm{p}$ - Statistical significance; $\mathrm{PR}_{\mathrm{u}}$ - Unadjusted prevalence ratio.

It was shown that $82.8 \%(79.5-85.8)$ presented other chronic health conditions, with $56 \%$ more association with limitations in ADLs ( $P R=1.56 ; 1.03-2.38)$, as well as being carriers of diabetes $(P R=$ $1.42 ; 1.01-1.99)$ and presenting physical disability $\left(\mathrm{PR}_{\mathrm{No}_{\mathrm{o}}}=0.63 ; 0.45-0.88\right)$. On the other hand, having good $(P R=0.41 ; 0.28-0.62)$ and average $(P R=0.59 ; 0.42-0.85)$ general health perceptions and not having perceptions of depressive symptoms $(P R=0.62 ; 0.47-0.81)$ and emotional oscillation $(P R=0.67$; 0.52 - 0.85 ) were less associated with limitations in ADL (Table 3 ).

Table 3: Descriptive and unadjusted analysis of clinical variables. 

$N(\%)$
IC $95 \%$
$\beta$
$\mathrm{t}$
$\mathrm{p}$
$\mathrm{PR}_{\mathrm{u}}$
IC $95 \%$

Other associated NCDs

\begin{tabular}{llllllll}
\hline Yes & $680(82.8 \%)$ & $79.5-85.8$ & 0.45 & 2.09 & 0.04 & 1.56 & $1.03-2.38$ \\
\hline No & $125(17.2 \%)$ & $14.2-20.5$ & 0 & & & 1 & \\
\hline
\end{tabular}

Diabetes

\begin{tabular}{llllllll}
\hline No & $650(83.9 \%)$ & $80.7-86.7$ & -0.35 & 2.07 & 0.03 & 0.70 & $0.50-0.98$ \\
\hline Yes & $124(16.1 \%)$ & $13.3-19.3$ & 0 & & & 1 & \\
\hline
\end{tabular}

Hypertension

\begin{tabular}{llllllll} 
Normal & $637(75.0 \%)$ & $70.4-79.0$ & -0.26 & -1.67 & 0.10 & 0.77 & $0.56-1.05$ \\
\hline Hypertense & $199(25.0 \%)$ & $21.0-29.6$ & 0 & & & 1 &
\end{tabular}

Disabilities

\begin{tabular}{llllllll}
\hline No & $657(73.4 \%)$ & $68.4-77.9$ & -0.46 & -2.68 & 0.01 & 0.63 & $0.45-0.88$ \\
\hline Yes & $182(26.6 \%)$ & $22.1-31.6$ & 0 & & & 1 & \\
\hline
\end{tabular}

Health self-perception

\begin{tabular}{llllllll}
\hline Good & $273(34.3 \%)$ & $30.5-38.4$ & -0.88 & -4.27 & $<0.01$ & 0.41 & $0.28-0.62$ \\
\hline Average & $403(47.1 \%)$ & $42.7-51.4$ & -0.52 & -2.89 & $<0.01$ & 0.59 & $0.42-0.85$ \\
\hline Poor & $163(18.6 \%)$ & $15.5-22.1$ & 0 & & & 1 & \\
\hline
\end{tabular}

Perception of mood oscillation

\begin{tabular}{llllllll} 
No & $472(59.1 \%)$ & $54.3-63.7$ & -0.40 & -3.22 & $<0.01$ & 0.67 & $0.52-0.85$ \\
\hline Yes & $367(40.9 \%)$ & $36.3-45.7$ & 0 & & & 1 & \\
\hline
\end{tabular}

Perception of depressive symptoms

\begin{tabular}{llllllll} 
No & $376(48.1 \%)$ & $43.4-52.9$ & -0.48 & -3.47 & $<0.01$ & 0.62 & $0.47-0.81$ \\
\hline Yes & $463(51.9 \%)$ & $47.1-56.6$ & 0 & & & 1 &
\end{tabular}

$\mathrm{N}$ - number of participants; \% - ratio; IC - Confidence interval; $\beta$ - Unadjusted regression coefficient; $\mathrm{t}$ - $\mathrm{t}$ test for the comparison between levels; $\mathrm{p}$ - Statistical significance; $\mathrm{PR}_{\mathrm{u}}$ - Unadjusted prevalence ratio.

It was found that $80 \%(95 \% \mathrm{Cl}: 76.1 \%-83.5 \%)$ of the individuals did not possess smoking habits, although those with fewer limitations in ADL did not adhere to tobacco abstinence and smoked on a daily basis ( $P R=0.54 ; 0.36-0.81$ ) or almost daily ( $P R=0.07 ; 0.02-0.24)$, even with renal functional changes. On the other hand, it was found that the individuals with limitations in ADL adhered to good life habits, including not drinking more than once a month, not smoking and practicing physical activity $(P R=1.52$; 
1.13 - 2.05). Most did not have health insurance (65.4\%; 61.2\% -69.3\%), and individuals who reported health insurance were more functional $(P R=0.46 ; 0.33-0.63)$ (Table 4).

Table 4: Descriptive and unadjusted analysis of lifestyle variables.

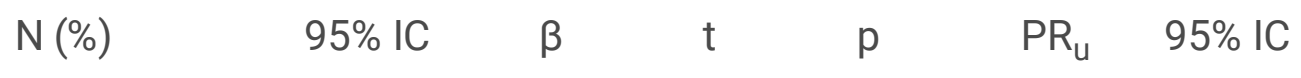

Regular physical activity

Sedentary

Active

Smoking habit

Yes, daily

Yes, less than daily

Don't smoke

Family Social Support

$\leq 1$ people

2 - 3 people

4 or more people

Friend Social Support

\begin{tabular}{lcllllll}
\hline$\leq 1$ people & $520(59.8 \%)$ & $54.7-64.7$ & -0.15 & -0.94 & 0.35 & 0.86 & $0.63-1.17$ \\
\hline $2-3$ people & $178(22.0 \%)$ & $17.9-26.8$ & -0.25 & -1.03 & 0.30 & 0.78 & $0.48-1.25$ \\
\hline 4 or more people & $141(18.2 \%)$ & $15.1-21.8$ & 0 & & & 1 & \\
\hline Last doctor visit & & & & & & & \\
\hline Last twelve months & $717(87.3 \%)$ & $84.6-89.6$ & 0.42 & 1.40 & 0.16 & 1.52 & $0.85-2.73$ \\
\hline From 1 to 2 years & $52(5.8 \%)$ & $4.0-8.2$ & -0.03 & -0.07 & 0.94 & 0.97 & $0.44-2.13$ \\
\hline From 2 to 3 years & $31(2.2 \%)$ & $1.6-3.1$ & $<0.01$ & 0.01 & 0.99 & 1.00 & $0.47-2.15$ \\
\hline 3 or more years & $39(4.8 \%)$ & $3.5-6.5$ & 0 & & & 1 & \\
\hline Family Health team visit in the last year? & & & & & & \\
\hline Monthly & $210(41.7 \%)$ & $36.0-47.5$ & -0.16 & -1.01 & 0.32 & 0.85 & $0.61-1.17$ \\
\hline Less than monthly & $199(42.1 \%)$ & $36.2-48.3$ & 0.07 & 0.26 & 0.79 & 1.08 & $0.62-1.87$ \\
\hline Never & $98(16.2 \%)$ & $13.5-19.3$ & 0 & & & 1 &
\end{tabular}

\begin{tabular}{lllllll}
$733(85.6 \%)$ & $82.2-88.4$ & 0.44 & 1.61 & 0.10 & 1.55 & $0.90-2.66$ \\
\hline $106(14.4 \%)$ & $11.6-17.8$ & 0 & & 1 & &
\end{tabular}

$121(18.4 \%) \quad 15.1-22.3 \quad-0.62 \quad-3.01 \quad<0.01 \quad 0.54 \quad 0.36-0.81$

$14(1.6 \%) \quad 0.8-3.0 \quad-2.71 \quad-4.20 \quad<0.01 \quad 0.07 \quad 0.02-0.24$

$704(80.0 \%) \quad 76.1-83.5 \quad 0 \quad 1$

$\begin{array}{lllllll}370(39.1 \%) & 34.8-43.6 & 0.09 & 0.55 & 0.58 & 1.09 & 0.79-1.51\end{array}$

$246(32.4 \%) \quad 28.0-37.1 \quad-0.01 \quad-0.04 \quad 0.97 \quad 0.99 \quad 0.68-1.45$

$223(28.5 \%) \quad 24.7-32.8 \quad 0$

1 
$\mathrm{N}$ - number of participants; \% - ratio; IC - confidence interval; $\beta$ - unadjusted regression coefficient; $\mathrm{t}$ - $\mathrm{t}$ test for the comparison between levels; $\mathrm{p}$ - Statistical significance; $\mathrm{PR}_{\mathrm{u}}$ - unadjusted prevalence ratio.

To understand the relationship of the independent variables with the outcome, controlling their interactions, it was important to perform an adjusted analysis of the data presented in Table 05.

Therefore, it was possible to infer fewer limitations in $A D L$ in individuals who claimed to have a good (PR $=0.64 ; 0.42-0.97)$ and moderate $(P R=0.72 ; 0.55-0.94)$ perception of their own health, not had depressive symptoms $(P R=0.72 ; 0.55-0.94)$ or physical disability $(P R=0.62 ; 0.47-0.82)$, those who lived in urban areas $(P R=0.75 ; 0.60-0.94)$ and those with private health insurance $(P R=0.51 ; 0.35-0.73)$. Furthermore, people who smoked daily $(P R=0.36 ; 0.20-0.64)$ or almost daily $(P=0.05 ; 0.01-0.17)$ were associated with fewer limitations in $A D L$, as well as those who did not undergo drug treatment for CKD-related comorbidities $(P R=1.40 ; 1.09-1.80)$ and the individuals who did not undergo hemodialysis $\left(\mathrm{PR}_{\mathrm{yes}}=2.30\right.$; 1.74-3.03) (Table 5).

Table 5. Adjusted analysis of factors related to interference in daily activities in individuals with chronic kidney disease in the Brazilian population. 


\begin{tabular}{lll} 
Limitations in Activities of Daily Living & $\mathrm{PR}_{\text {adjus }}$ & $\mathrm{IC} 95 \%$ \\
\hline Color & & \\
\hline White & 0.92 & $0.70-1.21$ \\
\hline Nonwhite & 1 & \\
\hline Lives with a partner & & \\
\hline Yes & 0.91 & $0.74-1.12$ \\
\hline No & 1 & \\
\hline Education level & & \\
\hline Graduation/Post-Graduation & 1.37 & $0.85-2.20$ \\
\hline High school & 0.68 & $0.42-1.11$ \\
\hline Primary school & 0.60 & $0.38-0.94$ \\
\hline Preschool & 0.66 & $0.41-1.07$ \\
\hline Illiterate & 1 & \\
\hline Social class & 0.82 & $0.62-1.07$ \\
\hline NCDs & & \\
\hline Yes & 1.04 & $0.66-1.62$ \\
\hline No & 1 & \\
\hline Diabetes & 1.11 & $0.82-1.50$ \\
\hline Yes & 1 & \\
\hline No & & \\
\hline Phy & & \\
\hline
\end{tabular}

Physical disability

\begin{tabular}{lll} 
No & 0.62 & $0.47-0.82$ \\
Yes & 1 & \\
\hline
\end{tabular}

Health perception

\begin{tabular}{lll} 
Good & 0.64 & $0.42-0.97$ \\
\hline Average & 0.72 & $0.55-0.94$ \\
Poor & 1 & \\
\hline
\end{tabular}

Perception of depressive symptoms No

$0.72 \quad 0.55-0.94$


Perception of mood lability

\begin{tabular}{lll}
\hline No & 0.86 & $0.66-1.12$ \\
\hline Yes & 1 & \\
\hline Smoking habit & & \\
\hline Daily & 0.36 & $0.20-0.64$ \\
\hline Nondaily & 0.05 & $0.01-0.17$ \\
\hline Does not smoke & 1 & \\
\hline Drugs for CKD-related comorbidities & & \\
\hline Yes & 1.40 & $1.09-1.80$ \\
\hline No & 1 & \\
\hline Hemodialysis & & \\
\hline Yes & 2.30 & $1.74-3.03$ \\
\hline No & 1 & \\
\hline Health insurance & & \\
\hline Yes & & \\
\hline No & 0.51 & $0.35-0.73$ \\
\hline Paid work & 1 & \\
\hline Yes & & \\
\hline No & 1.01 & $0.74-1.37$ \\
\hline Area of residence & 1 & \\
\hline Urban & & \\
\hline Rural & & \\
\hline
\end{tabular}

PR - Prevalence ratio; IC - Confidence interval.

\section{Discussion}

This study aimed to assess the association between individual and contextual factors of CKD patients and limitations in ADL in the Brazilian population. Almost half of the Brazilian population with CKD has limitations in terms of daily living habits, directly or indirectly related to biopsychosocial factors. Less limitations in ADL were mainly related to factors such as a good/average health perception, living in 
urban areas, and having access to private health insurance. On the other hand, presenting some type of physical or intellectual disability, continuous drug use, and undergoing hemodialysis were factors related to greater limitations in ADL.

Factors such as the individual's color, age, sex and paid work were not associated with inequality due to the limitations in $A D L$, even though the predominance of CKD diagnosis in the population was from 30 to 50 years. Low education level implied a higher limitation in ADL because of their interference with the behavior and health of individuals. People with greater educational vulnerabilities were more economically vulnerable as soon as they were more sedentary, obese, alcoholic and smokers, with a higher prevalence of NCDs, such as CKD (TONELLI; RIELLA, 2014). These diseases are added to the social inequalities that befall this population group and, in the nonwhite population, which affect the conditions and use of healthcare services, complicating the insertion in health education programs and other public prevention policies (MALTA; MOURA; BERNAL, 2015).

Another sociodemographic variable that was directly related to limitations in $A D L$ in individuals with CKD was the area of residence. The population that lived in urban areas presented fewer limitations than that in rural areas. This occurs because the inhabitants of rural areas possess different values due to their formation based on the symbolism of the land and intimately associate their health with the ability to perform fieldwork, and while this is not affected by diseases, they feel healthy. This fact decreases the perception of chronic diseases and generates a lower demand for healthcare services. Lower access to healthcare facilities is another important factor since these facilities are concentrated in urban areas, demanding locomotion and availability from these individuals. Thus, it is necessary local and regional public policies toward the population in rural areas, aiming at providing equitable care and the possibility of early diagnosis (ARRUDA; MAIA; ALVES, 2018).

Interestingly, it was shown that patients who used continuous drug use presented greater daily living limitations than those who did not. It is necessary to be careful with the interpretation of this inference since it does not mean that drugs worsen functionality but rather that CKD is an insidious and minimally symptomatic disease, favoring nonadherence to therapy, which only occurs when the disease becomes more severe. Furthermore, insufficient information for patients can corroborate nonadherence to therapy, especially in the early stages of the disease (SGNAOLIN; FIGUEIREDO, 2012). It can be inferred that individuals who use these drugs are often in later stages of the disease and possess more limitations. It is worth noting that the nonuse of drugs due to nonadherence to therapy can be an aggravating factor for the disease (ALMEIDA et al., 2019).

It was also verified that hemodialysis corroborated greater daily living limitations. Hemodialysis is associated with several physical consequences, such as arterial hypotension, vomiting, dizziness, cramps, headache, and fainting (TERRA et al., 2010). This procedure decreases the quality of life and causes personal, familiar, and social repercussions. CKD impacts the routine of daily activities, such as diet, traveling, feeding, work, and social life, in addition to generating dependence in these individuals to perform dialysis sessions (JESUS et al., 2019). 
Even with such complications, hemodialysis is still one of the safest and most effective procedures to replace renal function and promote a greater quality of life for individuals with CKD. On the other hand, peritoneal dialysis increases without bringing individual and social restrictions, since it can be performed inside the patient's home, the ability to cause fewer changes in the daily routine and an alternative encouraged by specific policies to improve patients' lives (MORAES et al., 2018). Most likely, the greater social care for contextual adequations and the emphasis on the education of patients in RRT can better explain the decision making between hemodialysis and peritoneal dialysis (XUE et al., 2019).

Furthermore, peritoneal dialysis is a more cost-effective procedure for the healthcare system (WANG et al., 2018; GHANI; RYDELL; JARL, 2019).

Other important aspects approach the perception of depressive symptoms, observed in more than half of CKD patients. CKD requires specific treatment and demands adaptation and changes in lifestyle, which can make individuals more likely to present anxiety and depression symptoms. Furthermore, these demanded changes can result in social isolation and loss of functional, physical, or mental performance, which may directly limit the life of these individuals (PRELJEVIC et al., 2013).

Health self-perception is also a useful indicator to evaluate individual health and synthesize its physical, mental, and social dimensions (SAEZ; VIDIELLA-MARTIN; CASASNOVAS, 2019). Furthermore, it can indicate the effectiveness of health education, which provides society with better health situations and life habits. The adjusted analysis of the results showed an inversely proportional relationship, in which the better the health perception by the individual is, the lower his limitations in daily living. The tracking of health perception seems to be a useful instrument in health services to identify individuals prone to clinical and functional decline and risk of death (INUZUKA et al., 2018).

Individuals with private health insurance were able to minimize the limitations in the daily living of people with CKD. Having private health insurance may be related to social status and greater access to favorable living conditions, as well as to healthcare services. The supplementary system can increase the flexibility and rate of examinations and procedures, often providing greater convenience and ease for individuals able to pay for it, therefore reflecting the reduction of complications and limitations caused by this disease (ZIROLDO; GIMENES; CASTELO JUNIOR, 2013).

Analysis of smoking habit variables revealed an intriguing scenario according to the adjusted analysis: people who smoked presented fewer daily living limitations than those who did not currently smoke. People with CKD who still smoke are probably in the early stages of CKD or still do not suffer great consequences from smoking (ELIHIMAS JUNIOR et al., 2014). It is also inferred that those people who do not smoke may have abandoned this habit for already being in more severe stages of CKD and presenting an impaired health status. Based on this, it is important to establish early educational and assistance actions to stimulate the reduction of tobacco products to delay the limitations caused by this habit.

Furthermore, it was revealed that individuals with CKD face greater daily living limitations when also presenting some degree of physical disability. These limitations, when associated, can extend beyond the 
habits and routine of these people and interfere, for example, with transportation to health facilities, therapeutic interventions, and emotional health (RAMÍREZ-PERDOMO; SOLANO-RUÍZ, 2018).

Finally, it is worth noting that among the limitations verified in the study, the transversality of the study is highlighted for preventing the establishment of cause-effect relationships between variables, as well as the fact that the outcome was evaluated through self-reports and not by the official record of the medical diagnosis, although it is described that several morbidities present good sensitivity to self-reports.

\section{Conclusions}

The study suggests that patients with CKD had limitations in ADL related mainly to psychosocial factors such as smoking, education, access to health services and care modality. Public health policies need to consider these aspects of users for the organization of health services and systems, mainly to mitigate the reduction in quality of life, less adherence to treatment and worsening of the clinical condition with higher costs to the security system.

\section{References}

1. ALMEIDA, O.A. et al. Engaging people with chronic kidney disease in their own care an integrative review. Ciência \& Saúde Coletiva, v.24, n.5, p.1689-1698, 2019. https://doi.org/10.1590/141381232018245.04332019

2. ARRUDA, N.M.; MAIA, A.G.; ALVES, L.C. Desigualdade no acesso à saúde entre as áreas urbanas e rurais do Brasil: uma decomposição de fatores entre 1998 a 2008. Cadernos de Saúde Pública, v.34, n,6, p.e00213816, 2018. https://doi.org/10.1590/0102-311x00213816.

3. CRUZ, MARIA CAROLINA et al. Quality of life in patients with chronic kidney disease. Clinics [online]. 2011, v. 66, n. 6 [Accessed 23 September 2021], pp. 991-995. Available from: <https://doi.org/10.1590/S1807-59322011000600012>.

4. ELIHIMAS JÚNIOR, U.F. et al. Smoking as risk factor for chronic kidney disease: systematic review. Jornal Brasileiro de Nefrologia, v.36, n.4, p.519-528, 2014. https://doi.org/10.5935/01012800.20140074 .

5. GHANI, Z.; RYDELL, H.; JARL, J. The Effect of Peritoneal Dialysis on Labor Market Outcomes Compared with Institutional Hemodialysis. Peritoneal Dialysis International, v.39, n.1, p.59-65, 2019. https://doi.org/10.3747/pdi.2017.00236.

6. HILL, N.R. et al. Global Prevalence of Chronic Kidney Disease - A Systematic Review and MetaAnalysis. PloS One, v.11, n.7, e0158765, 2016. https://doi.org/10.1371/journal.pone.0158765.

7. HO JUN CHIN, SHIN YOUNG AHN, JIWON RYU, et al. Renal function and decline in functional capacity in older adults. Age and Aging, Volume 43, Issue 6, November 2014, Pages 833-838, https://doi.org/10.1093/aging/afu071

8. INUZUKA, S. et al. Self-rated health status and illiteracy as death predictors in a Brazilian cohort. PloS One, v.13, n.7, e0200501, 2018. https://doi.org/10.1371/journal.pone.0200501. 
9. JESUS, N.M. et al. Quality of life of individuals with chronic kidney disease on dialysis. Jornal Brasileiro de Nefrologia, v.41, n.3, p.364-374, 2019. https://doi.org/10.1590/2175-8239-jbn-20180152.

10. KETTELER, M. et al. Executive summary of the 2017 KDIGO chronic kidney disease-mineral and bone disorder (CKD-MBD) guideline update: what's changed and why it matters. Kidney International, v.92, n.1, p.26-36, 2017. https://doi.org/10.1016/j.kint.2017.04.006

11. Lanza, A.H. et al. Perfil biopsicossocial de pacientes renais crônicos em tratamento hemodialítico. Arquivos Brasileiros de Ciências da Saúde, v.33, n.3, 2008. https://doi.org/10.7322/abcs.v33i3.148.

12. MALTA, D.C.; MOURA, L.; BERNAL, R.T. Differentials in risk factors for chronic noncommunicable diseases from the race/color standpoint. Ciência \& Saúde Coletiva, v.20, n.3, p.713-725, 2015. https://doi.org/10.1590/1413-81232015203.16182014.

13. MORAES, A.S. et al. Changes in occupational performance of individuals with chronic kidney disease undergoing peritoneal dialysis. Revista Família, Ciclos de Vida e Saúde no Contexto Social, v.6, p.591-599, 2018. https://doi.org/10.18554/refacs.v6i0.3129.

14. OLIVEIRA JUNIOR, H.M.; FORMIGA, F.F.; ALEXANDRE, C.S. Clinical and epidemiological profile of chronic hemodialysis patients in João Pessoa - PB. Jornal Brasileiro de Nefrologia, v.36, n.3, p.367374, 2014. https://doi.org/10.5935/0101-2800.20140052.

15. OLIVEIRA, A.P. et al. Quality of life in hemodialysis patients and the relationship with mortality, hospitalizations and poor treatment adherence. Jornal Brasileiro de Nefrologia, v.38, n.4, p.411-420, 2016. https://doi.org/10.5935/0101-2800.20160066.

16. OTTAVIANI, A.C. et al. Association between anxiety and depression and quality of life of chronic renal patients on hemodialysis. Texto \& Contexto Enfermagem, v.25, n.3, e00650015, 2016. https://doi.org/10.1590/0104-07072016000650015.

17. PRELJEVIC, V.T. et al. Anxiety and depressive disorders in dialysis patients: association to healthrelated quality of life and mortality. General Hospital Psychiatry, v.35, n.6, p.619-624, 2013. https://doi.org/10.1016/j.genhosppsych.2013.05.006.

18. RAMÍREZ-PERDOMO, C.A. SOLANO-RUÍZ, M.C. Social construction of the experience of living with chronic kidney disease. Revista Latino-Americana de Enfermagem, v.26, e3028, 2018. https://doi.org/10.1590/1518-8345.2439.3028

19. RIBEIRO, I.P. et al. Perfil epidemiológico dos portadores de insuficiência renal crônica submetidos à terapia hemodialítica. Enfermagem em Foco, v.5, p.65-69, 2014. https://doi.org/10.21675/2357707X.2014.v5.n3/4.567.

20. SAEZ, M.; VIDIELLA-MARTIN, J.; CASASNOVAS, G.L. Impact of the great recession on self-perceived health in Spain: a longitudinal study with individual data. BMJ Open, v.9, n.1, e023258, 2019. https://doi.org/10.1136/bmjopen-2018-023258.

21. SAMPAIO, R.M. et al. Perfil epidemiológico de pacientes nefropatas e as dificuldades no acesso ao tratamento. Revista Brasileira em Promoção da Saúde, v.26, n.1, p.94-100, 2013. https://doi.org/10.5020/2635. 
22. SGNAOLIN, V.; FIGUEIREDO, A.E. Adesão ao tratamento farmacológico de pacientes em hemodiálise. Jornal Brasileiro de Nefrologia, v.34, n.2, p.109-116, 2012. https://doi.org/10.1590/S010128002012000200002.

23. SOUZA-JUNIOR, P.R. et al. Sampling Design for the National Health Survey, Brazil 2013. Revista Epidemiologia e Serviços de Saúde, v.24, n.2, p.207-216, 2015. https://doi.org/10.5123/S167949742015000200003.

24. TERRA, F.S. et al. As principais complicações apresentadas pelos pacientes renais crônicos durante as sessões de hemodiálise. Revista Brasileira de Clínica Médica, v.8, n.3, p.187-192, 2010.

25. THOMÉ, F.S. et al. Brazilian Chronic Dialysis Survey 2017. Jornal Brasileiro de Nefrologia, v.41, n.2, p.208-214, 2019. https://doi.org/10.1590/2175-8239-JBN-2018-0178.

26. TONELLI, M.; RIELLA, M. Chronic kidney disease and the aging population. Jornal Brasileiro de Nefrologia, v.36, n.1, p.1-5, 2014. https://doi.org/10.5935/0101-2800.20140001.

27. WANG, V. et al. Medicare's new prospective payment system on facility provision of peritoneal dialysis. Clinical Journal of the American Society of Nephrology, v.13, n.12, p.1833-1841, 2018. https://doi.org/10.2215/CJN.05680518.

28. WATANABE, T., KUTSUNA, T., YONEKI, K. et al. Determinants of difficulty in activities of daily living in ambulatory patients undergoing hemodialysis. Ren Replace Ther 4, 8 (2018).

https://doi.org/10.1186/s41100-018-0146-y

29. WEBSTER, A.C. et al. Chronic kidney disease. The Lancet, v.389, p.1238-1252, 2017. https://doi.org/10.1016/S0140-6736(16)32064-5.

30. XUE, J. et al. Comparison of peritoneal dialysis with hemodialysis on survival of diabetic patients with end-stage kidney disease: a meta-analysis of cohort studies. Renal Failure, v.41, n.1, p.521-531, 2019. https://doi.org/10.1080/0886022X.2019.1625788.

31. ZIROLDO, R.R.; GIMENES, R.O.; CASTELO JUNIOR, C. An importância da Saúde Suplementar na demanda da prestação dos serviços assistenciais no Brasil. O Mundo Saúde, v.37, n.2, p.216-221, 2013. 